\title{
Nefritis Purpura Henoch Schonlein
}

\author{
Marissa Tania Stephanie Pudjiadi, Taralan Tambunan \\ Divisi Nefrologi Departemen Ilmu Kesehatan Anak Fakultas Kedokteran Universitas Indonesia, RS Dr. \\ Cipto Mangunkusumo, Jakarta
}

\begin{abstract}
Nefritis Henoch-Schonlein adalah purpura Henoch Schonlein (PHS) dengan keterlibatan ginjal. Manifestasi nefritis Henoch-Schonlein antara lain hematuria mikroskopik, hematuria makroskopis, proteinuria, sampai gagal ginjal kronik. Patogenesis PHS belum diketahui secara pasti, namun secara umum diakibatkan oleh deposisi imun kompleks akibat polimer IgA pada kulit, saluran gastrointestinal, dan kapiler glomerulus. Klasifikasi nefritis Henoch-Schonlein berdasarkan The International Study of Kidney Disease in Children terbagi atas enam kelas. Purpura Henoch Schonlein umumnya bersifat self-limiting dan hanya memerlukan terapi simtomatik. Keterlibatan ginjal diobati sesuai dengan manifestasi yang terjadi. Keterlibatan ginjal maupun rekurensi tidak dapat diprediksi dari gambaran histologi, sehingga diperlukan pemantauan jangka panjang. (Sari Pediatri 2009;11(2):102-7).
\end{abstract}

Kata kunci: purpura Henoch-Schonlein, nefritis Henoch-Schonlein

$\mathrm{P}$ urpura Henoch Schonlein (PHS) merupakan suatu vaskulitis sistemik dengan karakteristik dijumpai deposisi kompleks imun yang mengandung antibodi IgA pada kulit dan ginjal. Umumnya diderita oleh anak usia 3-10 tahun, dengan predominasi anak laki-laki. Insidens PHS bervariasi dari 13,5-24/100.000 kasus tahun. Etiologi pasti PHS belum diketahui dengan jelas. Kadang-kadang terjadi mengikuti suatu episode infeksi saluran pernapasan akut dan di negara dengan empat musim, lebih sering terjadi pada musim dingin. Salah satu patogen yang sering menyebabkan PHS adalah Streptococcus $\beta$ hemolyticus, yang terbukti dengan

\footnotetext{
Alamat korespondensi

Prof. Dr. Taralan Tambunan, Sp.A(K). Divisi Nefrologi. Departemen Ilmu Kesehatan Anak Fakultas Kedokteran Universitas Indonesia Jl. Salemba no. 6, Jakarta 10430. Telepon: 021-3915179. Fax.021-390 7743.
}

ditemukannya antigen streptokokus di dalam glomerulus pasien nefritis PHS. Keadaan lain yang juga dilaporkan berhubungan dengan terjadinya PHS antara lain gigitan serangga dan alergi makanan. ${ }^{1-4}$

Awitan PHS umumnya akut. Gejala yang khas adalah ditemukannya purpura yang dapat diraba, nyeri persendian, dan nyeri abdomen. Ketiga gejala merupakan trias klasik PHS dan dapat timbul bersamaan atau berselang satu sampai dua hari. Purpura dijumpai pada seluruh kasus PHS dengan predileksi pada ekstremitas bawah sampai daerah gluteus, namun kadang-kadang dapat pula dijumpai pada tangan, muka, dan badan. Nyeri persedian dijumpai pada $80 \%$ kasus terutama pada pergelangan kaki, lutut, dan siku. Nyeri abdomen ditemukan pada $62 \%$ kasus berupa kolik abdomen, disertai mual, muntah, konstipasi, atau diare. Gejala lain yang sering ditemukan antara lain perdarahan saluran cerna dan keterlibatan ginjal. ${ }^{1,5-7}$ 


\section{Definisi}

Nefritis Henoch-Schonlein adalah PHS dengan keterlibatan ginjal, yaitu hematuria mikroskopik (4\%-100\%), hematuria makroskopis (8\%-80\%), dan proteinuria (45\%-100\%). Walaupun jarang, dapat terjadi gagal ginjal kronik disertai dengan oliguria, retensi cairan, hipertensi, dan kerusakan ginjal lainnya dalam derajat yang bervariasi. Nefritis Henoch-Schonlein dijumpai pada 20\%-40\% kasus dan merupakan penyebab morbiditas utama pada PHS. Manifestasi klinis pada umumnya timbul dalam waktu tiga bulan dari awitan PHS, bahkan setelah gejala PHS lainnya menghilang. Faktor risiko yang menyebabkan terjadinya nefritis Henoch-Schonlein adalah usia awitan terjadinya PHS kurang dari tujuh tahun, nyeri abdomen berat yang disertai dengan perdarahan saluran cerna, pupura yang menetap lebih dari satu bulan, dan aktivitas faktor XIII koagulasi $<80 \%$. $^{1,8}$

\section{Patologi}

Secara patologi didapatkan purpura Henoch-Schonlein adalah kelainan glomerulonefritis proliferatif dengan lesi glomerulus yang menyerupai nefropati-IgA. Umumnya lesi yang terjadi berupa proliferasi mesangial fokal segmental ringan, namun pada kasus berat lesi dapat berupa glomerulonefritis proliferatif difus dengan kresen seperti pada glomerulonefritis progresif cepat (Gambar 1.A). ${ }^{3}$

Pemeriksaan imunofluoresensi pada biopsi ginjal ditemukan deposit granular IgA dan C3 dalam mesangium (Gambar.1.B). Kadang-kadang ditemukan pula pada sepanjang lumen kapiler. Imunoglobulin G, IgM, komponen komplemen C1q dan C4 jarang ditemukan, sedangkan fibrinogen sering terlihat. Endapan IgA juga terlihat pada dinding kapiler kulit, baik di daerah lesi purpura maupun pada kulit normal. Pemeriksaan mikroskop elektron menunjukkan endapan padat-elektron dan deposit humps subepitelial (Gambar 1.C). ${ }^{3,8}$

\section{Patogenesis}

Patogenesis PHS belum diketahui secara pasti, namun secara umum diakui sebagai akibat deposisi imun kompleks akibat polimer IgA pada kulit, saluran gastrointestinal, dan kapiler glomerulus. Keadaan patognomonik pada nefritis Henoch-Schonlein adalah deposisi IgA dan C3 yang ditemukan pada mesangial glomerulus. Penemuan patogenesis tersebut membedakan nefritis Henoch-Schonlein dengan nefropati IgA. ${ }^{8}$ Pada pasien sehat, IgA banyak ditemukan pada sekret mukosa namun dalam konsentrasi yang relatif rendah. Imunoglobulin A memiliki dua isotipe, yaitu $\operatorname{Ig} \mathrm{A}_{1}$ dan $\operatorname{Ig} \mathrm{A}_{2}$. Imunoglobulin $\mathrm{A}_{1}$ memiliki hinge region yang terdiri dari lima oligosakarida yang mengandung serine-linked $N$-acetylgalactosamine $(G a 1 N A c)$ dan galaktosa yang nantinya akan tersialasi (Gambar 2). Sekitar 60\% IgA dalam sekret adalah IgA yang umumnya berupa polimer sedangkan IgA serum umumnya berupa $\operatorname{IgA} A_{1}$ yang $90 \%$ berupa monomer. Pada nefritis Henoch-Schonlein ditemukan deposisi kompleks imun dengan predominasi IgA namun tidak ditemukan $\operatorname{IgA}_{2} \cdot 3,8$
A

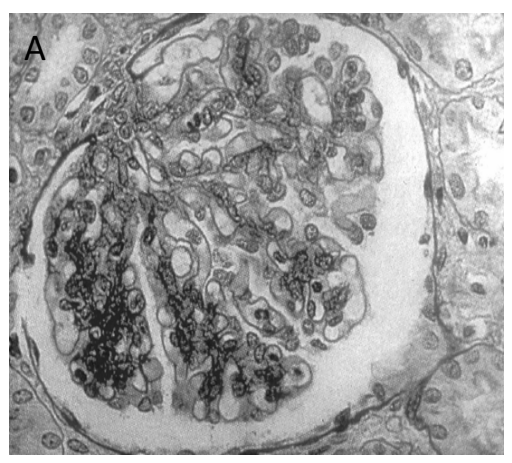

B

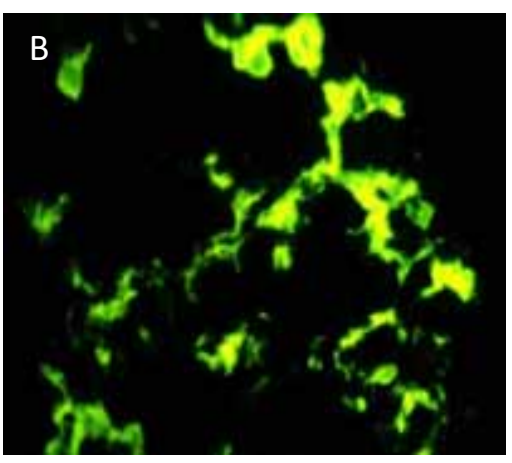

C

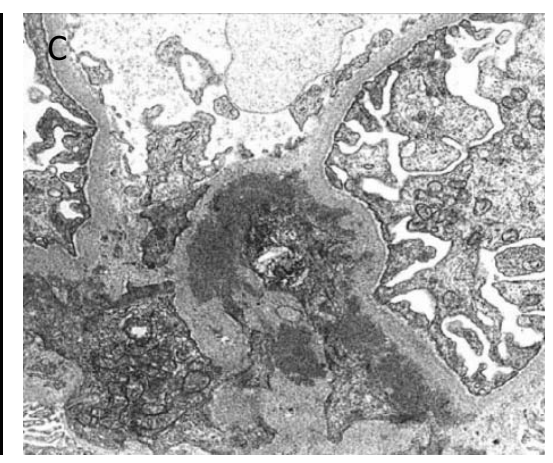

Gambar 1. A. Mikroskop cahaya B. Mikroskop imunofluoresens C. Mikroskop elektron ${ }^{8}$ 
A

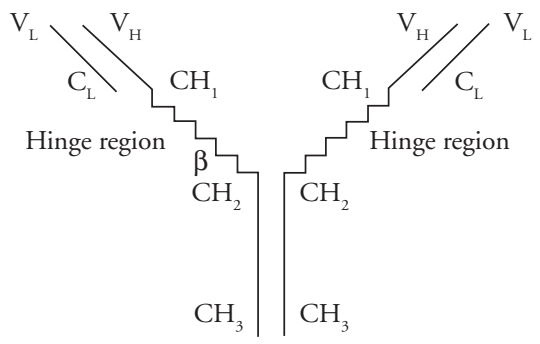

B

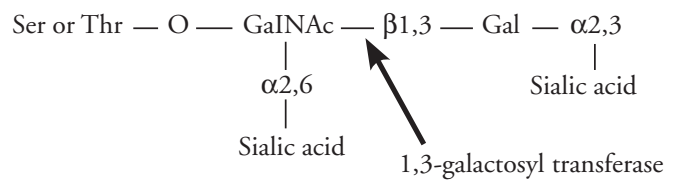

Gambar 2. Struktur IgA1 normal

Deposisi kompleks imun IgA terjadi berdasarkan peningkatan sintesis IgA atau penurunan klirens IgA. Peningkatan sintesis IgA oleh sistem imun mukosa sebagai respon terhadap paparan antigen pada mukosa dipikirkan merupakan mekanisme yang terjadi pada PHS. Hiperaktivitas sel B dan sel T terhadap antigen spesifik dilaporkan berperan dalam terjadinya PHS dan nefropati IgA. Antigen tersebut antara lain berupa antigen bakteri, protein dalam makanan seperti gliadin, dan komponen matriks ekstraselular seperti kolagen dan fibronektin. ${ }^{3,5,8}$ Beberapa studi mengemukakan terdapat peningkatan produksi IgA dalam sel mukosa dan tonsil, sedangkan studi lainnya mendapatkan penurunan produksi IgA dalam sel mukosa namun terjadi peningkatan produksi IgA dalam sumsum tulang. Hal ini ditunjukkan dengan peningkatan kadar IgA serum yang meningkat sampai 40\%-50\%. Selain itu, juga didapatkan gangguan pengikatan IgA $\mathrm{A}_{1}$ oleh reseptor asialoglycoprotein di hati, yang berfungsi pada klirens IgA dari sirkulasi. ${ }^{3,8}$

Kompleks imun IgA dalam kapiler dapat merupakan akibat deposisi kompleks imun yang berasal dari sirkulasi ataupun pembentukan kompleks imun in situ dalam glomerulus. Bukti klinis menemukan bahwa kompleks imun dalam sirkulasi bukan merupakan satu-satunya penyebab terjadinya deposisi kompleks imun, misalnya deposisi IgA dalam mesangium tetap ditemukan walau tidak ditemukan IgA dalam sirkulasi (50\% kasus). Kadar IgA di sirkulasi yang tinggi tidak cukup menyebabkan terjadi deposisi IgA dalam mesangium. Dibuktikan pada pasien dengan HIV atau mieloma dengan kadar IgA yang rendah tidak memiliki deposit kompleks imun IgA pada mesangium. Perubahan pada struktur biokimia IgA merupakan penyebab terjadi deposisi IgA dalam kapiler. Pada PHS dan nefropati IgA, IgA serum menunjukkan abnormalitas pada region $O$-glycosylated, yaitu hilangnya terminal galaktosa pada IgA sirkulasi. Selain itu, pada sel B juga ditemukan defek pada $\beta-1,3-$ galactosyltransferasi. Kelainan glikosilasi pada hinge region, akan menyebabkan perubahan pada stuktur IgA dan menyebabkan perubahan terhadap interaksi pada matriks protein, reseptor IgA, dan komplemen. Kelainan terebut akan menyebabkan terjadi deposit di dalam mesangium dan menyebabkan kerusakan lebih lanjut (Gambar 3). 3,8

Mediator inflamasi seperti interleukin-1 (IL-1), IL-6, platelet-derived growth factor, tumor necrosis factor, free radicals, prostanoid, leukotriens, membrane attack complex (C5b-9), dan circulating immunostimulatory protein (90K) menyebabkan terjadi kerusakan pada glomerulus lebih lanjut. Deposit C3 dan properdin tanpa ada C1q dan C4 merupakan keadaan yang khas dan menandakan jalur alternatif komplemen teraktivasi. 3, 5,8

\section{Diagnosis}

Diagnosis nefritis Henoch-Schonlein berdasarkan gejala klinis dan pemeriksaan laboratorium. Gejala klinis antara lain purpura yang dapat teraba yang tidak berhubungan dengan trombositopenia, nyeri abdomen yang dapat disertai perdarahan saluran cerna, artritis atau artralgia, hematuria dengan atau tanpa proteinuria dan disfungsi ginjal, serta vaskulitis

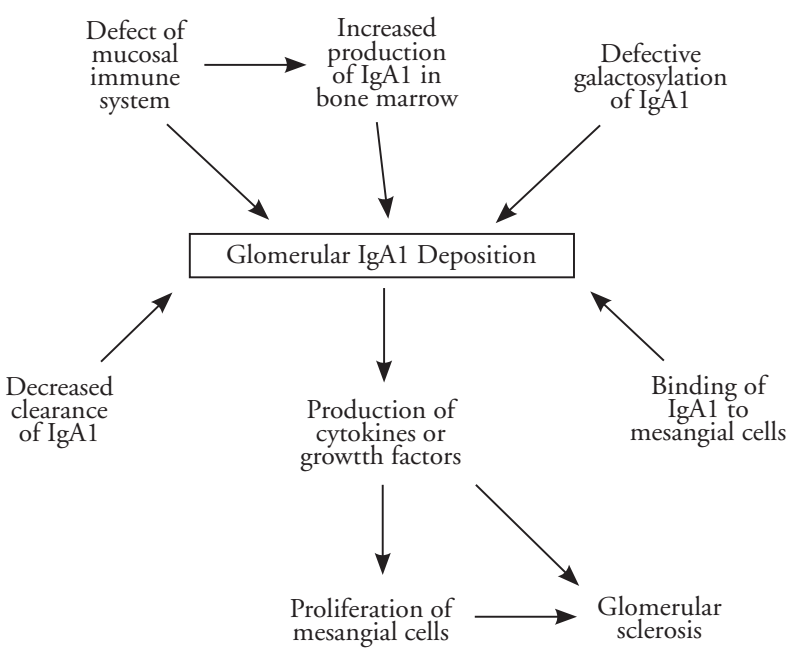

Gambar 3. Mekanisme terjadinya deposit IgA1 pada glomerulus dan progresivitas terjadinya kerusakan ginjal 
leukositoklastik dengan deposit IgA di dalam arteriol atau venula. Gejala klinis dianggap memenuhi kriteria diagnosis apabila terdapat lebih atau sama dengan tiga gejala tersebut. ${ }^{2,6,8}$

Pada pemeriksaan darah tepi dapat dijumpai anemia normositik normokrom yang diakibatkan perdarahan saluran cerna, leukositosis, dengan jumlah trombosit yang normal atau sedikit meningkat. Kadar $C$-reactive protein (CRP) dan laju endap darah (LED) normal atau sedikit meningkat. Pemeriksaan antinuclear antibody dan faktor rheumatoid menunjukkan hasil negatif, sedangkan pemeriksaan komplemen (C3 dan C4) normal. Pemeriksaan kadar kreatinin dan urea darah menunjukkan peningkatan. Pada urinalisis dapat dijumpai hematuria mikroskopik ataupun makroskopik (gross), dan proteinuria. Pada lebih dari 50\% kasus didapatkan peningkatan kadar IgA serum. Pada beberapa kasus juga dapat terlihat antinuclear cytoplasmic antibodies (ANCA) atau antiendothelial cell antibodies (AECA). ${ }^{6,8,9}$

Biopsi ginjal tidak dilakukan pada semua pasien PHS. Indikasi biopsi ginjal dilakukan apabila dijumpai PHS dengan proteinuria (sindrom nefrotik), PHS dengan hematuria dan proteinuria (sindrom nefritik), dan penurunan fungsi ginjal yang progresif. Biopsi ginjal dapat dilakukan untuk menegakkan diagnosis atau untuk mengetahui derajat keterlibatan ginjal. Pada umumnya hasil biopsi menunjukkan peningkatan sel mesangium, leukosit, dan terbentuk lesi cresent. Hasil tersebut menyerupai hasil biopsi pada nefropati IgA.,7,9

\section{Klasifikasi nefritis Henoch-Schonlein}

Klasifikasi nefritis Henoch-Schonlein berdasarkan The International Study of Kidney Disease in Children yang tertera pada Tabel 1.1,8

\section{Tata laksana}

Purpura Henoch Schonlein pada umumnya bersifat self-limiting dan hanya memerlukan terapi simtomatik. Gejala akan bertahan selama lebih kurang empat minggu dan akan berkurang secara spontan sampai akhirnya menghilang. Pada sepertiga kasus dijumpai relaps. ${ }^{1,3,4,8,9}$

Gejala persendian seperti artritis, artralgia, ataupun inflamasi jaringan lunak diobati dengan analgesik seperti asetaminofen atau obat anti inflamasi nonsteroid. Keterlibatan gastrointestinal termasuk akut abdomen atau perdarahan saluran cerna memiliki respon yang baik terhadap pemberian prednisolon oral jangka pendek. Dosis prednisolon $1-2 \mathrm{mg} / \mathrm{kg} /$ hari selama 1 minggu, dilanjutkan dengan tapering off selama 2-3 minggu (Tabel 2). ${ }^{1,} 7$

Panduan tata laksana nefritis Henoch-Schonlein yang ada saat ini masih belum memiliki bukti klinis yang memadai. Pemberian kortikosteroid jangka pendek sebagai usaha untuk mencegah terjadinya nefritis Henoch-Schonlein tidak direkomendasikan. Untuk kelainan mikroskopis seperti hematuria mikroskopis dan/atau proteinuria non-nefrotik dengan fungsi ginjal yang normal diperlukan pemantauan sampai duabelas bulan untuk melihat progresifitas keterlibatan ginjal. Bila terjadi sindrom nefrotik atau sindrom nefritis akut, terapi dimulai dengan kombinasi prednisolon $(2 \mathrm{mg} / \mathrm{kg} /$ hari selama $4 \mathrm{minggu}$, dilanjutkan dengan $1,5 \mathrm{mg} / \mathrm{kg}$ diberikan selang sehari selama 4 minggu, dan dilanjutkan tapering off dengan dosis $0,5 \mathrm{mg} / \mathrm{kg}$ diberikan selang sehari) dan azathioprin $(1-2 \mathrm{mg} / \mathrm{kg} /$ hari) selama 6-12 bulan (Tabel 2). ${ }^{1}$

Pada rapidly progressive (crescentic) glomerulonephritis, tata laksana yang diberikan adalah metilprednison pulse dosis tinggi tiga sampai enam kali. Dosis 20-30 $\mathrm{mg} / \mathrm{kg}$, diberikan selang sehari, dilanjutkan prednisolon

Tabel 1. Klasifikasi nefritis Henoch-Schonlein berdasarkan The International Study of Kidney Disease in Children

\begin{tabular}{ll}
\hline Kelas I & Kelainan minor pada glomerulus \\
Kelas II & Proliferasi mesangial (a. fokal; b. difus) \\
Kelas III & Kelainan minor pada glomerulus atau proliferasi mesangial dengan lesi segmental/kresen pada $<50 \%$ \\
& glomerulus (a. fokal; b. proliferasi mesangial difus) \\
Kelas IV & $\begin{array}{l}\text { Kelainan minor pada glomerulus atau proliferasi mesangial dengan lesi segmental } / \text { kresen pada 50-75\% } \\
\text { glomerulus (a. fokal; b. proliferasi mesangial difus) }\end{array}$ \\
Kelas V & $\begin{array}{l}\text { Kelainan minor pada glomerulus atau proliferasi mesangial dengan lesi segmental/kresen pada }>75 \% \\
\text { glomerulus (a. fokal; b. proliferasi mesangial difus) }\end{array}$ \\
Kelas VI & Lesi yang menyerupai glomerulonefritis membranoproliferatif \\
\hline
\end{tabular}




\title{
Nefritis Purpura Henoch Schonlein
}

\author{
Marissa Tania Stephanie Pudjiadi, Taralan Tambunan \\ Divisi Nefrologi Departemen Ilmu Kesehatan Anak Fakultas Kedokteran Universitas Indonesia, RS Dr. \\ Cipto Mangunkusumo, Jakarta
}

\begin{abstract}
Nefritis Henoch-Schonlein adalah purpura Henoch Schonlein (PHS) dengan keterlibatan ginjal. Manifestasi nefritis Henoch-Schonlein antara lain hematuria mikroskopik, hematuria makroskopis, proteinuria, sampai gagal ginjal kronik. Patogenesis PHS belum diketahui secara pasti, namun secara umum diakibatkan oleh deposisi imun kompleks akibat polimer IgA pada kulit, saluran gastrointestinal, dan kapiler glomerulus. Klasifikasi nefritis Henoch-Schonlein berdasarkan The International Study of Kidney Disease in Children terbagi atas enam kelas. Purpura Henoch Schonlein umumnya bersifat self-limiting dan hanya memerlukan terapi simtomatik. Keterlibatan ginjal diobati sesuai dengan manifestasi yang terjadi. Keterlibatan ginjal maupun rekurensi tidak dapat diprediksi dari gambaran histologi, sehingga diperlukan pemantauan jangka panjang. (Sari Pediatri 2009;11(2):102-7).
\end{abstract}

Kata kunci: purpura Henoch-Schonlein, nefritis Henoch-Schonlein

$\mathrm{P}$ urpura Henoch Schonlein (PHS) merupakan suatu vaskulitis sistemik dengan karakteristik dijumpai deposisi kompleks imun yang mengandung antibodi IgA pada kulit dan ginjal. Umumnya diderita oleh anak usia 3-10 tahun, dengan predominasi anak laki-laki. Insidens PHS bervariasi dari 13,5-24/100.000 kasus tahun. Etiologi pasti PHS belum diketahui dengan jelas. Kadang-kadang terjadi mengikuti suatu episode infeksi saluran pernapasan akut dan di negara dengan empat musim, lebih sering terjadi pada musim dingin. Salah satu patogen yang sering menyebabkan PHS adalah Streptococcus $\beta$ hemolyticus, yang terbukti dengan

\footnotetext{
Alamat korespondensi

Prof. Dr. Taralan Tambunan, Sp.A(K). Divisi Nefrologi. Departemen Ilmu Kesehatan Anak Fakultas Kedokteran Universitas Indonesia Jl. Salemba no. 6, Jakarta 10430. Telepon: 021-3915179. Fax.021-390 7743.
}

ditemukannya antigen streptokokus di dalam glomerulus pasien nefritis PHS. Keadaan lain yang juga dilaporkan berhubungan dengan terjadinya PHS antara lain gigitan serangga dan alergi makanan. ${ }^{1-4}$

Awitan PHS umumnya akut. Gejala yang khas adalah ditemukannya purpura yang dapat diraba, nyeri persendian, dan nyeri abdomen. Ketiga gejala merupakan trias klasik PHS dan dapat timbul bersamaan atau berselang satu sampai dua hari. Purpura dijumpai pada seluruh kasus PHS dengan predileksi pada ekstremitas bawah sampai daerah gluteus, namun kadang-kadang dapat pula dijumpai pada tangan, muka, dan badan. Nyeri persedian dijumpai pada $80 \%$ kasus terutama pada pergelangan kaki, lutut, dan siku. Nyeri abdomen ditemukan pada $62 \%$ kasus berupa kolik abdomen, disertai mual, muntah, konstipasi, atau diare. Gejala lain yang sering ditemukan antara lain perdarahan saluran cerna dan keterlibatan ginjal. ${ }^{1,5-7}$ 


\section{Definisi}

Nefritis Henoch-Schonlein adalah PHS dengan keterlibatan ginjal, yaitu hematuria mikroskopik (4\%-100\%), hematuria makroskopis (8\%-80\%), dan proteinuria (45\%-100\%). Walaupun jarang, dapat terjadi gagal ginjal kronik disertai dengan oliguria, retensi cairan, hipertensi, dan kerusakan ginjal lainnya dalam derajat yang bervariasi. Nefritis Henoch-Schonlein dijumpai pada 20\%-40\% kasus dan merupakan penyebab morbiditas utama pada PHS. Manifestasi klinis pada umumnya timbul dalam waktu tiga bulan dari awitan PHS, bahkan setelah gejala PHS lainnya menghilang. Faktor risiko yang menyebabkan terjadinya nefritis Henoch-Schonlein adalah usia awitan terjadinya PHS kurang dari tujuh tahun, nyeri abdomen berat yang disertai dengan perdarahan saluran cerna, pupura yang menetap lebih dari satu bulan, dan aktivitas faktor XIII koagulasi $<80 \%$. $^{1,8}$

\section{Patologi}

Secara patologi didapatkan purpura Henoch-Schonlein adalah kelainan glomerulonefritis proliferatif dengan lesi glomerulus yang menyerupai nefropati-IgA. Umumnya lesi yang terjadi berupa proliferasi mesangial fokal segmental ringan, namun pada kasus berat lesi dapat berupa glomerulonefritis proliferatif difus dengan kresen seperti pada glomerulonefritis progresif cepat (Gambar 1.A). ${ }^{3}$

Pemeriksaan imunofluoresensi pada biopsi ginjal ditemukan deposit granular IgA dan C3 dalam mesangium (Gambar.1.B). Kadang-kadang ditemukan pula pada sepanjang lumen kapiler. Imunoglobulin G, IgM, komponen komplemen C1q dan C4 jarang ditemukan, sedangkan fibrinogen sering terlihat. Endapan IgA juga terlihat pada dinding kapiler kulit, baik di daerah lesi purpura maupun pada kulit normal. Pemeriksaan mikroskop elektron menunjukkan endapan padat-elektron dan deposit humps subepitelial (Gambar 1.C). ${ }^{3,8}$

\section{Patogenesis}

Patogenesis PHS belum diketahui secara pasti, namun secara umum diakui sebagai akibat deposisi imun kompleks akibat polimer IgA pada kulit, saluran gastrointestinal, dan kapiler glomerulus. Keadaan patognomonik pada nefritis Henoch-Schonlein adalah deposisi IgA dan C3 yang ditemukan pada mesangial glomerulus. Penemuan patogenesis tersebut membedakan nefritis Henoch-Schonlein dengan nefropati IgA. ${ }^{8}$ Pada pasien sehat, IgA banyak ditemukan pada sekret mukosa namun dalam konsentrasi yang relatif rendah. Imunoglobulin A memiliki dua isotipe, yaitu $\operatorname{Ig} \mathrm{A}_{1}$ dan $\operatorname{Ig} \mathrm{A}_{2}$. Imunoglobulin $\mathrm{A}_{1}$ memiliki hinge region yang terdiri dari lima oligosakarida yang mengandung serine-linked $N$-acetylgalactosamine $(G a 1 N A c)$ dan galaktosa yang nantinya akan tersialasi (Gambar 2). Sekitar 60\% IgA dalam sekret adalah IgA yang umumnya berupa polimer sedangkan IgA serum umumnya berupa $\operatorname{IgA} A_{1}$ yang $90 \%$ berupa monomer. Pada nefritis Henoch-Schonlein ditemukan deposisi kompleks imun dengan predominasi IgA namun tidak ditemukan $\operatorname{IgA}_{2} \cdot 3,8$
A

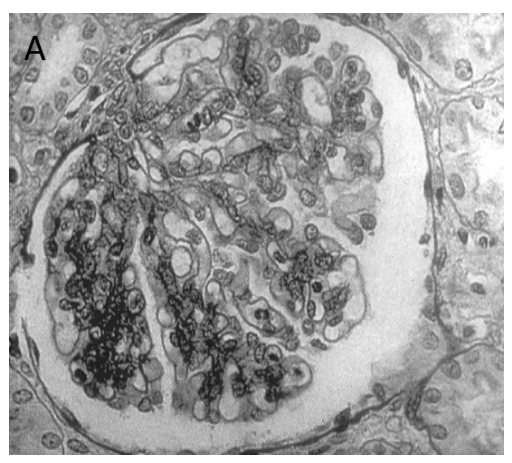

B

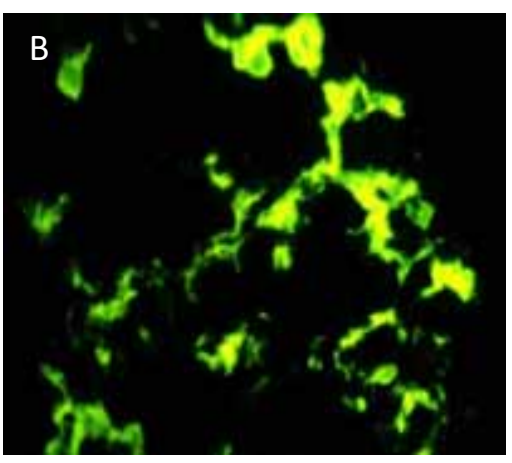

C

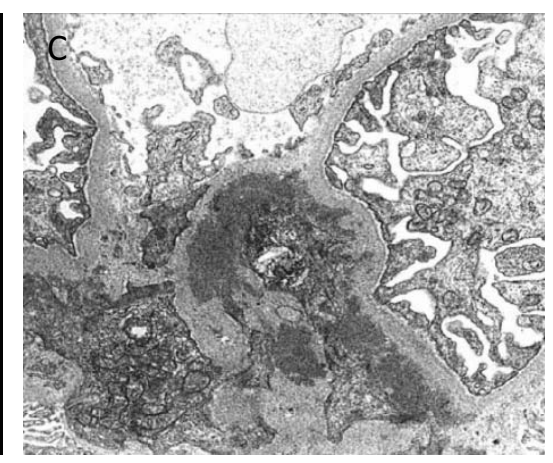

Gambar 1. A. Mikroskop cahaya B. Mikroskop imunofluoresens C. Mikroskop elektron ${ }^{8}$ 